\title{
Adrenal and clinical responses to corticotrophin and prednisone in inflammatory disease of the colon
}

\author{
M. FRIEDMAN, J. M. HINTON, ${ }^{1}$ AND J. E. LENNARD-JONES ${ }^{2}$ \\ From St Mark's Hospital, and University College Hospital, London
}

Clinical experience suggests that some patients with severe ulcerative colitis or Crohn's disease of the colon who are not responding to oral prednisone improve on treatment with corticotrophin. Why this is so is not known and the optimum dosage of corticotrophin has not been established. To investigate these two problems observations have been made on the effect of prednisone and/or corticotrophin on the adrenal function and clinical response in 20 patients with colonic inflammatory disease.

\section{METHOD}

PATIENTS Clinical details of the 20 patients studied are shown in Table I. The diagnosis was made on the basis

${ }^{1}$ In receipt of a grant from the Medical Research Council.

${ }^{2}$ Member of the Medical Research Council, Gastroenterology

Research Unit. of typical clinical, sigmoidoscopic, and radiological findings and the exclusion of bacterial and parasitic infection.

SCHEME OF TREATMENT Corticotrophin was used in eight patients who failed to respond to prednisone and in two patients who were so ill that it was used from the start. Preliminary observations suggested that the initial dose should be 80 units daily. Before the study began it was agreed that this dose should be continued for a minimum period of five days unless emergency surgical treatment was required, and that the dose should be reduced by decrements of 20 units in accordance with the clinical improvement.

Prednisone was used in 18 patients in a divided dose of 10 to $60 \mathrm{mg}$ daily (Table I) for at least two days before plasma cortisol levels were measured.

SCHEME OF INVESTIGATION A single batch of corticotrophin gel was used (Armour K. G. 2802). One intra-

TABLE I

DETAILS OF THE PATIENTS STUDIED AND THEIR RESPONSE TO PREDNISONE AND/OR CORTICOTROPHIN Clinical Details

\begin{tabular}{|c|c|c|c|c|c|c|}
\hline Patient & Sex and Age & $\begin{array}{l}\text { First Attack } \\
\text { or Relapse }\end{array}$ & Length of History & No. of Stools Daily & Weight Loss (lb) & Sigmoidoscopy \\
\hline 1 & F 28 & $\mathbf{R}$ & $1 \mathrm{yr}$ & 11 & $\mathbf{0}$ & Active \\
\hline 2 & F 44 & $\mathbf{R}$ & $5 \mathrm{yr}$ & 20 & 7 & Moderately active \\
\hline 3 & M 52 & $\mathbf{R}$ & $7 \mathrm{yr}$ & 6 & $\mathbf{0}$ & Moderately active \\
\hline 4 & M 28 & $\mathbf{F}$ & $3 \mathrm{mth}$ & 9 & 14 & Active \\
\hline 5 & F 28 & $\mathbf{F}$ & $2 \mathrm{mth}$ & 4-5 & 14 & Normal \\
\hline 6 & M 28 & $\mathbf{R}$ & $3 \mathrm{yr}$ & $5-8$ & $\mathbf{0}$ & Moderately active \\
\hline 7 & M 20 & $\mathbf{R}$ & $3 \mathrm{yr}$ & 2 & $\mathbf{0}$ & Inactive \\
\hline 8 & M 26 & $\mathbf{R}$ & $3 \mathrm{yr}$ & 14 & 4 & Moderately active \\
\hline 9 & F 22 & $\mathbf{R}$ & $4 \mathrm{yr}$ & 3 & $\mathbf{0}$ & Moderately active \\
\hline 10 & M 62 & $\mathbf{R}$ & $9 \mathrm{yr}$ & $5-6$ & 7 & Active \\
\hline 11 & M 19 & $\mathbf{F}$ & $5 \mathrm{mth}$ & $2-3$ & 8 & Inactive \\
\hline 12 & M 46 & $\mathbf{F}$ & $6 \mathrm{mth}$ & 18 & 28 & Active \\
\hline 13 & F 69 & $\mathbf{R}$ & $1 \mathrm{yr}$ & 5 & 12 & Moderately active \\
\hline 14 & F 23 & $\mathbf{R}$ & $4 \mathrm{yr}$ & 12 & 5 & Moderately active \\
\hline 15 & M 59 & $\mathbf{R}$ & $2 \mathrm{yr}$ & 16 & 7 & Moderately active \\
\hline 16 & M 63 & $\mathbf{R}$ & $33 \mathrm{yr}$ & 17 & 10 & Active \\
\hline 17 & M 44 & $\mathbf{R}$ & $16 \mathrm{yr}$ & 15 & $\mathbf{0}$ & Moderately active \\
\hline 18 & F 66 & $\mathbf{R}$ & $4 \mathrm{yr}$ & 19 & 4 & Active \\
\hline 19 & F 66 & $\mathbf{R}$ & $5 \mathrm{yr}$ & 7 & 30 & Moderately active \\
\hline 20 & M 25 & $\mathbf{R}$ & $1 \mathrm{yr}$ & 12 & 32 & Active \\
\hline
\end{tabular}

${ }^{1} \mathrm{~T}=$ Total, $\mathrm{E}=$ Extensive, $\mathrm{LS}=$ Left sided, PS $=$ Proctosigmoiditis. 
muscular injection was given daily between 9.00 and $10.00 \mathrm{am}$. Heparinized blood samples were collected between 9.00 and 10.00 am when the patients were on prednisone, in the majority of cases three hours after the morning dose, and when on ACTH immediately before and five, 12, and 24 hours after injection. The plasma was separated within 30 minutes of venepuncture and stored at $-4^{\circ} \mathrm{C}$ until the estimations were performed. The plasma cortisol was measured as free plasma total 11-hydroxycorticosteroids by a modification (Black and Friedman, 1965) of the fluorimetric method of Mattingly (1962). Where more than one series of measurements at each dose of corticotrophin was made on one patient the results are expressed as a mean each time. With this method the normal range of plasma cortisol at $9.00 \mathrm{am}$ is 8 to $28 \mu \mathrm{g}$ per $100 \mathrm{ml}$.

\section{RESULTS}

EFFECT OF CORTICOTROPHIN ON PLASMA CORTISOL The mean results at five, 12 , and 24 hours at each dosage for the individual patients are shown in Table II. The mean results for all the patients are summarized in Table III.

It will be seen that the peak values occurred five hours after the injection and that subsequent values were lower. The mean value five hours after 80 units was significantly greater than after 40 units and 20 units and the value five hours after 60 units was significantly greater than after 20 units.

The duration of response correlated with the size of the dose. At 12 hours the mean values after 80 units and 60 units were significantly greater than after 40 units and 20 units. At 24 hours the mean
TABLE II

MEAN PLASMA CORTISOL LEVELS AT FIVE, 12, AND 24 HOURS AFTER DIFFERENT DOSES OF CORTICOTROPHIN GEL

\begin{tabular}{|c|c|c|c|c|}
\hline \multirow[t]{2}{*}{ Patient } & \multirow{2}{*}{$\begin{array}{l}\text { Dose of } \\
\text { ACTH Gel } \\
\text { (units daily) }\end{array}$} & \multicolumn{3}{|c|}{$\begin{array}{l}\text { Mean Plasma Cortisol Level } \\
(\mu \mathrm{g} / 100 \mathrm{ml})\end{array}$} \\
\hline & & Five Hours & 12 Hours & 24 Hours \\
\hline \multirow[t]{4}{*}{4} & 80 & $138 \cdot 6$ & $57 \cdot 8$ & $15 \cdot 7$ \\
\hline & 60 & $97 \cdot 2$ & $53 \cdot 4$ & 11.0 \\
\hline & 40 & $54 \cdot 2$ & $9 \cdot 6$ & $5 \cdot 8$ \\
\hline & 20 & $35 \cdot 1$ & 5.0 & $8 \cdot 8$ \\
\hline \multirow[t]{4}{*}{8} & 80 & $55 \cdot 5$ & $23 \cdot 7$ & 8.7 \\
\hline & 60 & $35 \cdot 3$ & $17 \cdot 5$ & $14 \cdot 2$ \\
\hline & 40 & $37 \cdot 1$ & 6.0 & 10.0 \\
\hline & 20 & $34 \cdot 3$ & $4 \cdot 7$ & $7 \cdot 8$ \\
\hline \multirow[t]{4}{*}{12} & 80 & $83 \cdot 1$ & $79 \cdot 6$ & $23 \cdot 4$ \\
\hline & 60 & $71 \cdot 2$ & $52 \cdot 2$ & $10 \cdot 8$ \\
\hline & 40 & $47 \cdot 4$ & $23 \cdot 2$ & $6 \cdot 7$ \\
\hline & 20 & $42 \cdot 8$ & $8 \cdot 4$ & $8 \cdot 5$ \\
\hline $14^{1}$ & 80 & $58 \cdot 2$ & $41 \cdot 0$ & $45 \cdot 3$ \\
\hline \multirow[t]{4}{*}{15} & 80 & 69.9 & $50 \cdot 4$ & 28.9 \\
\hline & 60 & $72 \cdot 3$ & $44 \cdot 8$ & $11 \cdot 3$ \\
\hline & 40 & 51.6 & $22 \cdot 8$ & $4 \cdot 3$ \\
\hline & 20 & $51 \cdot 2$ & $20 \cdot 3$ & 11.0 \\
\hline $16^{1}$ & 80 & 77.0 & 98.0 & $73 \cdot 7$ \\
\hline \multirow[t]{4}{*}{17} & 80 & $66 \cdot 0$ & 43.9 & $25 \cdot 2$ \\
\hline & 60 & $73 \cdot 0$ & $61 \cdot 2$ & $7 \cdot 5$ \\
\hline & 40 & $73 \cdot 8$ & $39 \cdot 2$ & $6 \cdot 8$ \\
\hline & 20 & $46 \cdot 0$ & $14 \cdot 6$ & 9.4 \\
\hline \multirow[t]{4}{*}{$18^{1}$} & 80 & $112 \cdot 1$ & 105.5 & $51 \cdot 7$ \\
\hline & 60 & $132 \cdot 3$ & $88 \cdot 4$ & $37 \cdot 5$ \\
\hline & 40 & 35.0 & $33 \cdot 7$ & $23 \cdot 5$ \\
\hline & 20 & $74 \cdot 6$ & 10.4 & 20.7 \\
\hline \multirow[t]{4}{*}{19} & 80 & $78 \cdot 7$ & 68.9 & $37 \cdot 8$ \\
\hline & 60 & $61 \cdot 9$ & $39 \cdot 2$ & $24 \cdot 6$ \\
\hline & 40 & 87.6 & $59 \cdot 0$ & $23 \cdot 1$ \\
\hline & 20 & $85 \cdot 1$ & $33 \cdot 7$ & $26 \cdot 3$ \\
\hline \multirow[t]{4}{*}{$20^{1}$} & 80 & $106 \cdot 2$ & 66.4 & $21 \cdot 7$ \\
\hline & 60 & 86.4 & $25 \cdot 3$ & 6.9 \\
\hline & 40 & $48 \cdot 9$ & $10 \cdot 7$ & $8 \cdot 2$ \\
\hline & 20 & $44 \cdot 0$ & 6.8 & $5 \cdot 8$ \\
\hline
\end{tabular}

${ }^{1}$ Required surgical treatment.

DETAILS OF THE PATIENTS STUDIED AND THEIR RESPONSE TO PREDNISONE AND/OR CORTICOTROPHIN

\begin{tabular}{|c|c|c|c|c|c|}
\hline \multirow[t]{2}{*}{ Extent of Disease $^{1}$} & \multicolumn{4}{|l|}{ Prednisone } & \multirow[t]{2}{*}{$A C T H$} \\
\hline & Dose (mg daily) & $\begin{array}{l}\text { Duration of } \\
\text { Treatment (days) }\end{array}$ & $\begin{array}{l}\text { Plasma Cortisol Levels } \\
(\mu \mathrm{g} / 100 \mathrm{ml})\end{array}$ & Clinical Response & \\
\hline $\begin{array}{l}\text { E } \\
\text { E } \\
\text { LS } \\
\text { E } \\
\text { E } \\
\text { PS } \\
\text { E } \\
\text { T } \\
\text { E } \\
\text { LS } \\
\text { E } \\
\text { E } \\
\text { LS } \\
\text { T } \\
\text { L } \\
\text { L } \\
\text { E } \\
\text { T } \\
\text { E } \\
\text { T }\end{array}$ & $\begin{array}{l}30 / 10 \\
40 / 60 \\
30 \\
40 \\
40 \\
40 / 60 \\
20 \\
30 \\
30 / 60 \\
40 \\
15 \\
60 \\
40 \\
40 \\
20 / 30 \\
40 \\
30 / 40 \\
40\end{array}$ & $\begin{array}{l}41 \\
42-56 \\
7-14 \\
6-8 \\
2-7 \\
7-19 \\
35 \\
14-17 \\
4-35 \\
14-24 \\
101 \\
6-7 \\
8 \\
2-7 \\
42-43 \\
10 \\
12 \\
4-5\end{array}$ & $\begin{array}{l}0 \cdot 6 \\
1 \cdot 0,1 \cdot 2,3 \cdot 4 \\
1 \cdot 4,1 \cdot 2 \\
1 \cdot 6,4 \cdot 0 \\
1 \cdot 8,4 \cdot 4 \\
2 \cdot 0,2 \cdot 0,2 \cdot 6,3 \cdot 0 \\
2 \cdot 2 \\
2 \cdot 6,3 \cdot 6 \\
3 \cdot 0,3 \cdot 4,2 \cdot 0,1 \cdot 8,1 \cdot 8,2 \cdot 0,2 \cdot 2 \\
8 \cdot 8,3 \cdot 6 \\
9 \cdot 4 \\
11 \cdot 0,6 \cdot 4 \\
14 \cdot 6 \\
11 \cdot 0,6 \cdot 4,14 \cdot 8,17 \cdot 4 \\
8 \cdot 6,19 \cdot 0 \\
26 \cdot 8 \\
30 \cdot 0 \\
28 \cdot 0,44 \cdot 8\end{array}$ & $\begin{array}{l}\text { Improved } \\
\text { No change } \\
\text { No change } \\
\text { Worse } \\
\text { Remission } \\
\text { Remission } \\
\text { Remission } \\
\text { Worse } \\
\text { Remission } \\
\text { Improved } \\
\text { Improved } \\
\text { Worse } \\
\text { Remission } \\
\text { Worse } \\
\text { Worse } \\
\text { Worse } \\
\text { Worse } \\
\text { Worse }\end{array}$ & $\begin{array}{l}\text { Remission } \\
\text { Worse, surgery } \\
\text { Remission } \\
\text { Worse, surgery } \\
\text { Remission } \\
\text { Improved, surgery } \\
\text { Remission } \\
\text { Improved, surgery }\end{array}$ \\
\hline
\end{tabular}


TABLE III

MEAN PLASMA CORTISOL LEVELS FOR PATIENTS AT INTERVALS AFTER DIFFERENT DOSES OF CORTICOTROPHIN ${ }^{1}$ Plasma Cortisol Levels at Different Corticotrophin Injection ( $\mu \mathrm{g} \mathrm{per} 100 \mathrm{ml}^{2}$

\begin{tabular}{|c|c|c|c|}
\hline \multirow{2}{*}{ (units) } & \\
\hline & Five Hours & 12 Hours & 24 Hours \\
\hline \multirow[t]{2}{*}{$\begin{array}{l}80 \\
60 \\
40 \\
20\end{array}$} & $\begin{array}{l}84.5 \pm 8.4 \\
78.7 \pm 10.0 \\
54.5 \pm 6.3 \\
51.6 \pm 6.5\end{array}$ & $\begin{array}{l}63.5 \pm 8.1 \\
47.8 \pm 7.8 \\
25.5 \pm 6.3 \\
13.0 \pm 3.5\end{array}$ & $\begin{array}{l}33 \cdot 2 \pm 6 \cdot \\
15 \cdot 5 \pm 3 \cdot \\
11 \cdot 1 \pm 2 . \\
12 \cdot 3 \pm 2 .\end{array}$ \\
\hline & \multicolumn{3}{|c|}{ Significance of Differences at Each Time } \\
\hline $\begin{array}{l}80 \text { vs } 60 \\
80 \text { vs } 40 \\
80 \text { vs } 20 \\
60 \text { vs } 40 \\
60 \text { vs } 20 \\
40 \text { vs } 20\end{array}$ & $\begin{aligned} & \text { N.S. } \\
&< 0.02 \\
&< 0.01 \\
& \text { N.S. } \\
&< 0.05 \\
& \text { N.S. }\end{aligned}$ & $\begin{aligned} & \text { N.S. } \\
< & 0.01 \\
< & 0.001 \\
< & 0.05 \\
< & 0.01 \\
& \text { N.S. }\end{aligned}$ & $\begin{aligned}< & 0.05 \\
< & 0.02 \\
< & 0.05 \\
& \text { N.S. } \\
& \text { N.S. } \\
& \text { N.S. }\end{aligned}$ \\
\hline
\end{tabular}

'The significance of differences has been assessed by student's 't' test, each patient contributing a mean value at each time.

'Mean and SE.

value after 80 units was above the normal range and significantly greater than after all the smaller doses, following which the mean values were within the normal range.

CORRELATION OF CLINICAL RESPONSE TO CORTICOTROPHIN WITH PLASMA CORTISOL Of the 10 patients treated with corticotrophin six went into remission and left hospital free of symptoms. In two patients the improvement was limited and they were both treated surgically four weeks after admission. Two patients required surgery within one week of starting treatment, one for perforation, one because of clinical deterioration.

As may be seen in Table II the adrenal response to corticotrophin of the four patients who came to surgery did not differ from those who went into clinical remission.

EFFECT OF PREDNISONE ON PLASMA CORTISOL As May be seen in Table $I$, in nine patients plasma cortisol levels of $3 \mu \mathrm{g} / 100 \mathrm{ml}$ or below were observed indicating adrenal suppression by exogenous prednisone. However, an unexpected finding was that in seven patients the levels fell within the normal range and in two were above it. Seven of these nine patients were receiving $40 \mathrm{mg}$ or more of prednisone daily, while the remaining two received 15 and $20 \mathrm{mg}$ daily.

CORRELATION OF CLINICAL RESPONSE TO PREDNISONE WITH PLASMA CORTISOL Of the nine patients in whom plasma cortisol levels indicating adrenal suppression were observed, two failed to improve and required treatment with corticotrophin to which they responded. The remaining seven patients improved with treatment. Of the nine patients with normal or high plasma cortisol levels six failed to improve and all six required treatment with corticotrophin. Three of the six later required colectomy, the other three became symptom free.

\section{DISCUSSION}

The data on the response to various doses of ACTH suggest that increasing the dose of corticotrophin gel not only increases the peak response at five hours but also, and possibly more important, increases the duration of action.

The similarity between the plasma cortisol response of the patients who went into remission and of those who required surgery shows that the adrenal response to corticotrophin is not the only factor governing recovery.

An interesting finding was that in nine of the 18 patients on prednisone blood cortisol levels were normal or high, confirming the observation of Mattingly (1963) that the normal fall to very low levels may not occur in some patients with gastrointestinal disorders during corticosteroid therapy. This could mean that the prednisone is not absorbed, or that it is inactivated in the gut, or that the stress of the disease prevents the usual suppression of endogenous corticotrophin secretion by the drug. Since structural and functional changes in the small intestine are known to occur in patients with severe ulcerative colitis (Salem and Truelove, 1964), a failure of absorption could explain some of the instances in which blood cortisol levels were normal or high during oral prednisone therapy. Alternatively, while an increase in circulating corticosteroids normally suppresses corticotrophin secretion by the pituitary (Landon and Greenwood, 1968), this suppression may not occur under conditions of stress. For example, preoperative treatment with dexamethasone failed to prevent cortisol secretion in response to the stresses of laparotomy (Estep, Island, Ney, and Liddle, 1963) or insulin hypoglycaemia (James and Landon, 1963).

Further investigation is needed to account for the raised plasma cortisol levels in some of the patients receiving large doses of prednisone. Our results do not explain why some patients who did not improve with oral prednisone subsequently responded to corticotrophin.

\section{SUMMARY}

The adrenal response to corticotrophin was assessed by measuring serial plasma cortisol levels in 10 cases 
of severe colitis. It was found that increasing the dose of corticotrophin gel not only increased the peak levels but also increased the duration of action. No difference in adrenal response was detected between the six patients who responded to corticotrophin and the four who required surgery.

The plasma cortisol level was also measured in 18 patients with colitis being treated with oral prednisone and in nine patients values above $3 \mu \mathrm{g}$ per $100 \mathrm{ml}$ were found indicating possibly a failure of adrenal suppression. This finding could explain why some patients who fail to respond to treatment with oral prednisone subsequently respond to treatment with corticotrophin.

\section{REFERENCES}

Black, S., and Friedman, M. (1965). Adrenal function and the inhibition of allergic responses under hypnosis. Brit. med.J., 1, 562-567.

Estep, H. L., Island, D. P., Ney, R. L., and Liddle, G. W. (1963). Pituitary-adrenal dynamics during surgical stress. J. clin. Endocr., 23, 419-425.

James, V. H. T., and Landon, J. (1963). The response of the pituitaryadrenal axis to the infusion of dexamethasone. J. Endocr., 26, xxxi-xxxii.

Landon, J., and Greenwood, F. C. (1968). Homologous radioimmunoassay of plasma-levels of corticotrophin in man. Lancet, 1, 273-276.

Mattingly, D. (1962). A simple fluorimetric method for the estimation of free 11-hydroxycorticoids in human plasma. J. clin. Path., 15, 374-379.

- (1963). Plasma steroid levels as a measure of adrenocortical activity. Proc. roy. Soc. Med., 56, 717-720.

Salem, S. N., Truelove, S. C., and Richards, W. C. D. (1964). Smallintestinal and gastric changes in ulcerative colitis: a biopsy study. Brit. med. J., 1, 394-398. 